\title{
Ichthyoplankton of Arvoredo Biological Marine Reserve, Santa Catarina, Brazil
}

\author{
Thais Rutkowski, Paulo Ricardo Schwingel, Renan Todesco Brilha and \\ Marcelo Rodrigues-Ribeiro
}

Arvoredo Island, located in Santa Catarina state - south Brazil, and its surrounding area were defined as a Conservation Unit (CU) in the category of Biological Reserve since 1990. This research aimed to analyze the inter-annual and seasonal (winter and summer) variations of ichthyoplankton densities at Arvoredo Biology Marine Reserve (ABMR), and their relationship with environmental variables in 1997/1998 (Campaign 1), 2007/2008 (Campaign 2) and 2008/2009 (Campaign 3). Fish eggs and larvae were sampled using a WP-2 net with $200 \mu \mathrm{m}$ mesh size. The study area was influenced by three water masses, (i) Coastal Water throughout the whole year, (ii) Subtropical Shelf Water during the winter, and (iii) South Atlantic Central Water mainly in summer. A total of 4,891 eggs were collected and classified as Engraulidae and Sardinella brasiliensis (Clupeidae). The total number of larvae was 467 belonging to 5 orders, 19 families, and 21 species. Taxonomic composition demonstrated a seasonal pattern among periods, with the highest densities of Engraulidae occurring in winter and the families Carangidae, Clupeidae and Gerreidae in summer. The high number of families and abundance of ichthyoplankton observed in ABMR may be important in supplying the adjacent coastal areas impacted by fishing.

A Ilha do Arvoredo, localizada em Santa Catarina, Brasil, e sua região de entorno foram definidas como Unidade de Conservação, na Categoria de Reserva Biológica Marinha, em 1990. Este trabalho teve como objetivo analisar as variações sazonais (inverno e verão) e interanuais das densidades do ictioplâncton na região da Reserva Biológica Marinha do Arvoredo (RBMA), e suas relações com as variáveis ambientais em 1997/1998 (Campanha 1), 2007/2008 (Campanha 2) e 2008/2009 (Campanha 3). Os ovos e larvas de peixes foram coletados com uma rede WP-2 de $200 \mu \mathrm{m}$. A área de estudo foi influenciada por três massas d'água, (i) Água Costeira durante o ano todo, (ii) Água de Plataforma Subtropical durante o inverno, e (iii) Água Central do Atlântico Sul principalmente no verão. Um total de 4.891 ovos foram amostrados e classificados como Engraulidae e Sardinella brasiliensis (Clupeidae). Um total de 467 larvas foram coletadas e identificadas em 5 ordens, com 19 famílias e 21 espécies. A composição taxonômica mostrou sazonalidade entre os períodos, com as maiores densidades de Engraulidae no inverno e de Carangidae, Clupeidae e Gerreidae no verão. O número elevado de famílias e a abundância do ictioplâncton observada na RBMA podem ser importantes para o enriquecimento das áreas costeiras adjacentes impactadas pela pesca.

Key words: Biodiversity, Conservation Unit, Fish eggs, Fish larvae.

\section{Introduction}

Conservation units (CU) are protected areas that have their own rules for use and management, with the purpose of preservation and protection of plant or animal species, the scenic beauty and conservation of cultural and physical resources (IBAMA/GTZ, 1999). On the coast of Santa Catarina State, south Brazil, Arvoredo Island and its surrounding region were classified as Conservation Unit (CU) in the category Biological Reserve (IBAMA, 2006).
Arvoredo Biology Marine Reserve (ABMR) is located $11 \mathrm{~km}$ north of the island of Santa Catarina, in the coordinates of $27^{\circ} 09^{\prime} 30^{\prime \prime} \mathrm{S} 48^{\circ} 18^{\prime} 30^{\prime \prime} \mathrm{W}$ and $27^{\circ} 17^{\prime} 57^{\prime \prime} \mathrm{S}$ $48^{\circ} 25^{\prime} 30^{\prime \prime} \mathrm{W}$ (Fig. 1). This region covers a large area in the Atlantic Ocean, with 17,800 hectares and comprises a small archipelago of Arvoredo, Galé, Deserta, and Calhau de São Pedro islands (IBAMA, 2006). The ABMR is influenced by oceanographic processes that promote daily, seasonal and annual variations in the structure of water masses in this region and by physical and chemical changes promoted

Universidade do Vale do Itajaí, Rua Uruguai, 458, Centro, Caixa Postal 360, 88302-202 Itajaí, SC, Brazil. rutke_t@hotmail.com (TR); schwingel@univali.br(PRS); renan.todesco@gmail.com(RTB); mribeiro@univali.br (MRR) 
by continental discharge (Matsuura, 1986; Braga \& Niencheski, 2006).

Marine Protected Areas (MPA) acts as tools for both biodiversity conservation and fishery management. One example is the increased productivity of the areas surrounding the reserves, which can occur in two ways: (1) larger fish can migrate out of protected areas and be caught with a larger size, and (2) larger fish in protected areas can contribute with a larger number of eggs and larvae to the environment. Therefore, extensive marine reserves that are off limits for fishing activity, can contribute to management strategies, increasing productivity, reducing environmental impacts, increasing the stocks of sedentary organisms, size and age structure, fecundity, and potential spawning (Hilborn et al., 2004; Roberts et al. 2005, Bohnsack, 1999).

Hilborn et al. (2004) describe the lack of scientific studies in the areas of marine reserves, what makes it difficult to understand and evaluate the efficiency and success of these sites. In this sense, Rowely et al. (1994) demonstrate that studies are needed to understand the patterns of displacement and habitat for all stages of life cycle (larval, settlement, juvenile, adult, feeding, and reproduction) to implement more effective marine reserves. With this in mind this study proposed the description of the ichthyoplankton community in the ABMR and the influence of physical and chemical processes on the distribution and abundance of species which could serve as a basis for sizing the importance and efficiency of CU to adjacent areas.

\section{Material and Methods}

Sampling were conducted during the daytime in the legal limits of the Arvoredo Biology Marine Reserve (ABMR) and along the adjacent area, during the winter and summer in six stations in Campaign 1 (winter 1997 and summer 1998), twelve stations in Campaign 2 (winter 2007 and summer 2008) and twelve stations in Campaign 3 (winter 2008 and summer 2009). The campaigns in 2008 and 2009 used the same sampling stations of the previous year and six additional. The sampling sites were distributed at depths that ranged from 6 to 40 meters (Fig. 1, Table 1). Zooplankton was collected using a WP-2 net which is two meters long with $30 \mathrm{~cm}$ in mouth diameter and 200 $\mu \mathrm{m}$ in mesh size, equipped with a flowmeter to determine the volume of water filtered. Horizontal hauls were done near the surface with maximum speed of 2 knots and samples were immediately preserved in a formalin-seawater solution (4\%). In order to characterize the region of the ABMR ichthyoplankton samples were analyzed in a laboratory with eggs and fish larvae separated and quantified on Bogorov plates under binocular stereo microscopes. The identifications of ichthyoplankton were made at the lowest possible taxon, using specialized references (e.g. Fahay, 1983; Ré, 1999; Moser, 1996).

In Campaign 2 and 3 temperature and salinity were measured with a conductivity, temperature, depth (CTD) sensors (model SD-202, Saiv A/S ${ }^{\mathrm{TM}}$ ), allowing the identification of which water bodies were present at the ABMR, and generate vertical profiles
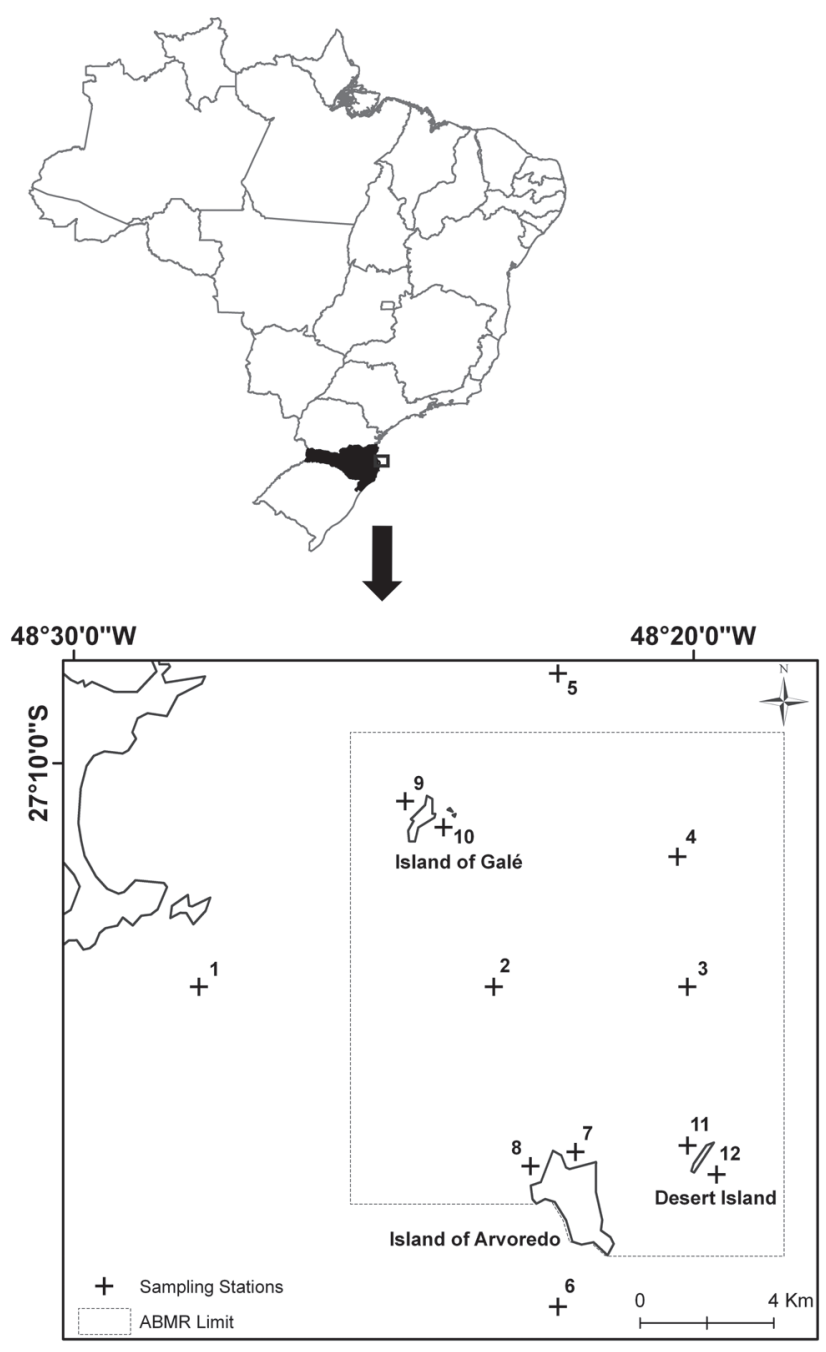

Fig. 1. Location of sampling stations in the Arvoredo Biology Marine Reserve region and adjacent areas in campaign 1 (1997/ 1998) (stations 7-12), campaign 2 (2007/2008) (stations 1-12) and campaign 3 (2008/2009) (stations 1-12).

of water column. Water masses were classified according to Castro et al. (2006) and Piola et al. (2000). The transparency was determined using a Secchi Disk and chlorophyll- $a$ was sampled in these two campaigns using $120 \mathrm{~mL}$ of sea surface water filtered in situ on glass filter of $25 \mathrm{~mm}$ in diameter. In the laboratory chlorophyll- $a$ was calculated using the technique of high performance liquid chromatography efficiency (CLAE) (Proença, 2002).

A one-way analysis of variance was applied to compare the interannual variation of egg and larvae densities among sampling campaigns in two situations: between three winters $(1997,2007,2008)$ and three summers $(1998,2008,2009)$ using only six sites (7-12) that were coincident for the three campaigns. In addition, seasonal differences within each campaign were tested using all the sample points. Because data did not show homogeneity of variances by Bartlett's 
Table 1. Sampling period described in the Arvoredo Biology Marine Reserve (Brazil) region.

\begin{tabular}{ccc}
\hline Sampling Campaign & Date & Sampling Stations \\
\hline Campaign 1 & $\begin{array}{c}14 / 08 / 1997 \text { (winter) } \\
24 / 01 / 1998 \text { (summer) }\end{array}$ & $06(7-12)$ \\
\hline Campaign 2 & $\begin{array}{c}14 / 08 / 2007 \text { (winter) } \\
13 / 02 / 2008 \text { (summer) }\end{array}$ & $12(1-12)$ \\
\hline Campaign 3 & $\begin{array}{c}26 / 09 / 2008 \text { (winter) } \\
23 / 03 / 2009 \text { (summer) }\end{array}$ & $12(1-12)$ \\
\hline
\end{tabular}

test, variables were transformed to $\log _{10}(\mathrm{x}+1)($ Zar, 1984). The posterior Tukey Unequal test was applied to identify significant differences (Gotelli \& Ellison, 2004). A cluster analysis was performed to identify similarities among sample locations, based on the abundance of different taxa that comprise the ichthyoplankton community. Similarity was measured by using the Euclidean Distance and Ward's Connection Method. In order to determine whether the number of larvae collected was sufficient to represent the species richness, rarefaction curves were generated (Ludwig \& Reynolds, 1988). A canonical correspondence analysis was applied to verify correlations between the physical and biological variables on the data matrix of larval abundance for each species (Ter Braak, 1986).

\section{Results}

In Arvoredo Biology Marine Reserve (ABMR) a total of 4,166 fish eggs were collected during the winter and 725 during the summer. During the winter of 1997, higher densities of eggs were observed reaching averages values of 181.5 eggs. $10 \mathrm{~m}^{-3}$. In the winter of 2007 , such density was lower, when was registered an average of 2.5 eggs. $10 \mathrm{~m}^{-3}$, while in 2008 this value increased to 248.9 eggs. $10 \mathrm{~m}^{-3}$ (Fig. 2a). In summer, a similar pattern was observed, with the lowest densities occurring in 2008 (7.1 eggs. $\left.10 \mathrm{~m}^{-3}\right)$ and the highest in 1998 and 2009 ( 21.0 and 26.3 eggs. $10 \mathrm{~m}^{-3}$, respectively). The analysis of variance showed significant differences between the average densities of eggs $(\mathrm{F}=4.52$ e $\mathrm{P}=0.019)$ during the sampling period in the winter of 2007 compared with the winters of 1997 and 2008 (Fig. 2a). For the summer period the density of eggs showed no significant difference between the years (Fig. 2a). Regarding seasonality, the analysis of variance showed a significant difference in the campaign, between winter 1997 and summer of 1998 (Campaign 1) and between winter 2008 and summer 2009 (Campaign 3) ( $\mathrm{F}=11.93$ e $\mathrm{P}=0.00005$ ) (Fig. 3a).

Eggs collected belonged to Engraulidae, Clupeidae (Sardinella brasiliensis), and not identified species (SI). In winter, the eggs of the Engraulidae were collected in the three years analyzed, representing 95.1\% (1997), 12.5\% (2007), and 60.6\% (2008) of relative abundance (RA) (Fig. 4a). In summer, the family Engraulidae has represented 20.3\% in 1998 and 5\% in 2008 The specie $S$. brasiliensis occurred only in summer with RA of $29.0 \%$ in $1998,21.7 \%$ in 2008 , and $4.7 \%$ in 2009 (Fig. 4b).

A total of 263 fish larvae were collected during the winter and 204 during the summer. In the winter of 1997, larvae occurred at low densities, an average of $3.7 \mathrm{eggs} .10 \mathrm{~m}^{-3}$. In the winter of 2007, the average density observed was 6.8 eggs. $10 \mathrm{~m}^{-3}$, and in 2008 it reached an average of 19.2 eggs. $10 \mathrm{~m}^{-3}$. The analysis of variance didn't showed significant differences among winter samples in the three campaign (Fig. 2b) ( $\mathrm{F}=7.24 \mathrm{e} \mathrm{P}=0.003)$. In the summer of 1998, the average density of larvae was 1.7 eggs. $10 \mathrm{~m}^{-3}$, and higher values were observed for 2008 and 2009, with 15.2 and 6.0 eggs. $10 \mathrm{~m}^{-3}$, respectively. The analysis of variance showed significant differences among between summer the 1998 and summer the 2008 (Fig 2b). Seasonal comparisons for each campaign showed significant differences in larval densities for Campaign 3 (Fig. 3b) ( $\mathrm{F}=9.74 \mathrm{e} \mathrm{P}=0.0002)$.
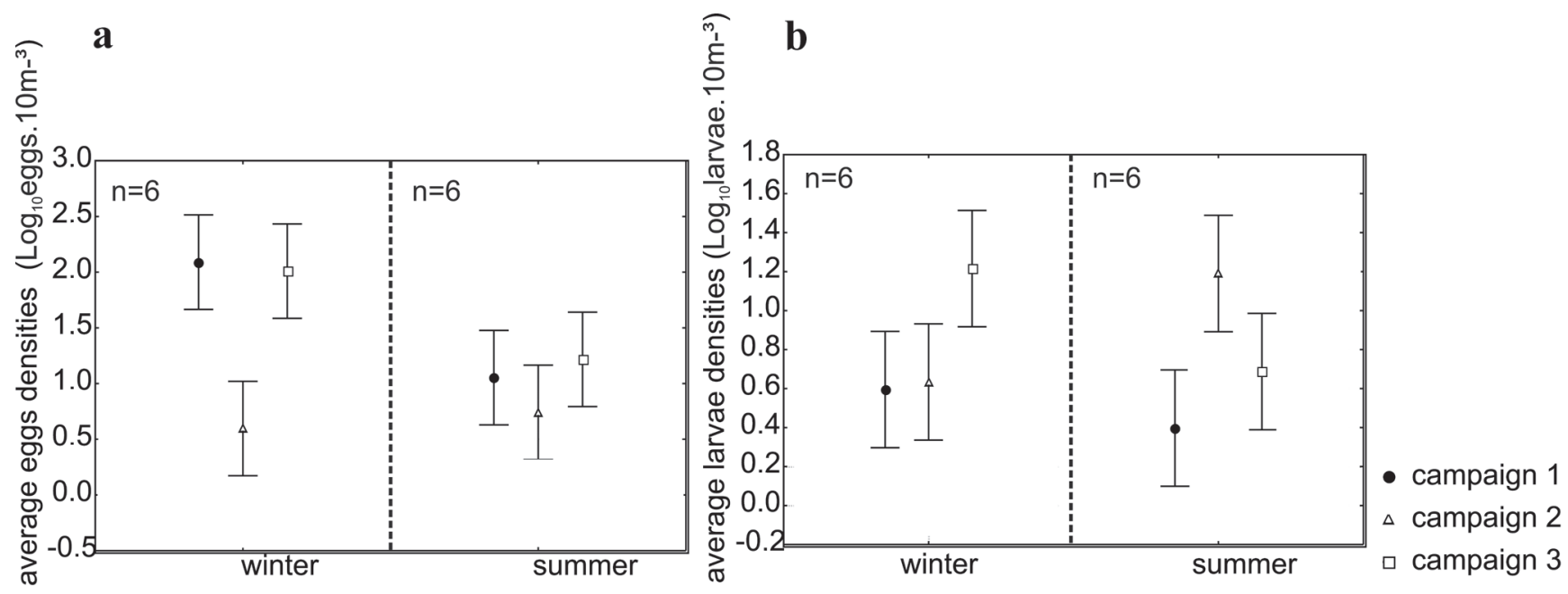

Fig. 2. Average densities of (a) eggs and (b) larvae collected during the winter and summer periods to six stations in the Arvoredo Biology Marine Reserve (Brazil) in different campaign (1- 1997/1998, 2- 2007/2008, and 3- 2008/2009). The vertical bar represents the confidence interval. 

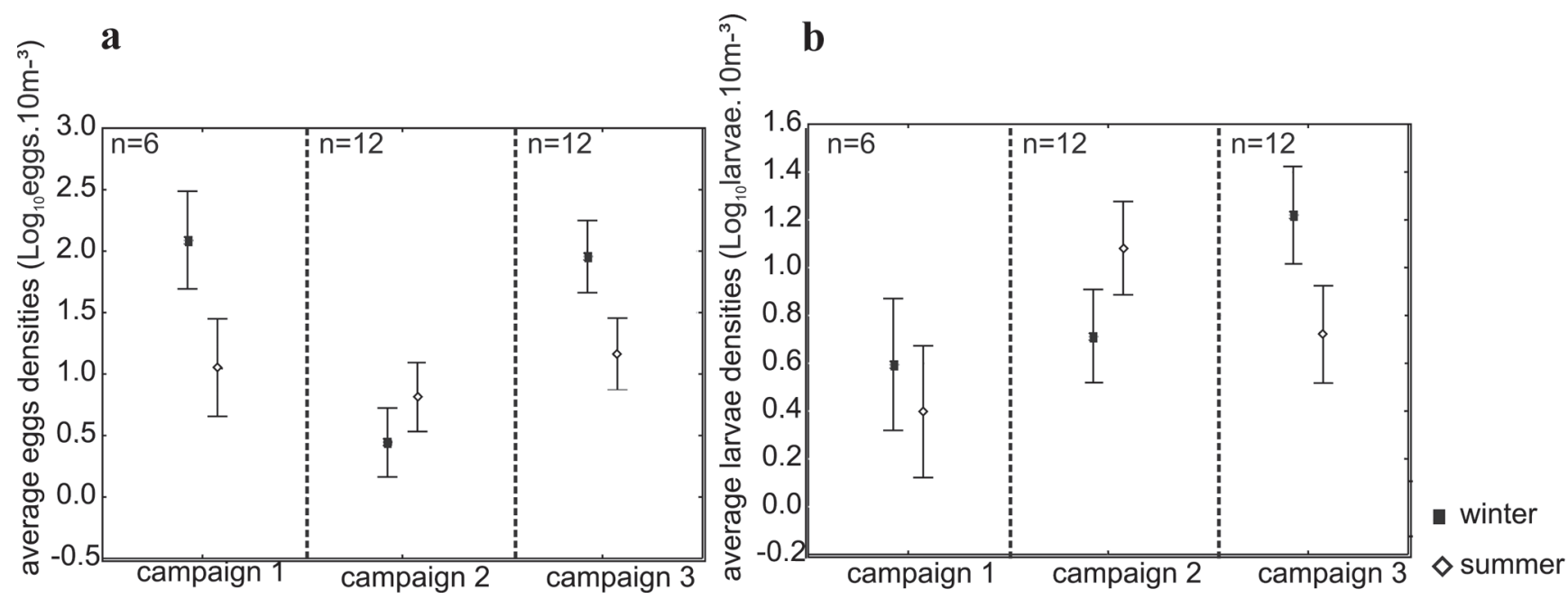

Fig. 3. Average densities of (a) eggs and (b) larvae collected in the Arvoredo Biology Marine Reserve (Brazil) in to six stations in campaign 1 (1997/1998), twelve stations in campaign 2 (2007/2008) and twelve stations in campaign 3 (2008/2009), during the winter and summer periods. The vertical bar represents the confidence interval.

In relation to larval stage, preflexion was predominant in the samples, which has resulted in taxonomic classification, for most individuals, in the family level. After the whole material of the three campaigns was indentified 19 families and 21 species were found (Table 2), being the taxa Mugil sp., Gerreidae, Harengula clupeola, Hypleurochilus fissicornis, Scartella cristata, Gobiidae, Sciaenidae, and Engraulidae the ones who showed the highest frequencies of occurrence (FO) $(\geq 10 \%)$ and relative abundance (RA) $(\geq 2 \%)$. In winter, the families that had the highest values of FO and RA were Blenniidae, Engraulidae, Gobiidae, and Sciaenidae (Fig. 5a), opposing from those found in summer that were represented by Carangidae, Clupeidae, Gerreidae,
Paralichthyidae, and Synodontidae. Engraulidae larvae were the most abundant in winter, ranging from 61.3 to $90.5 \%$. On the other hand, Clupeidae were the most abundant family in the summer of 1998 (39.3\%), Gerreidae in 2008 (26.4\%) and Carangidae in 2009 (24.4\%) (Fig. 5b). The analysis of similarity allowed the identification of two groups, one in summer and other in winter (Fig. 6), indicating a strong seasonality in the composition of ichthyoplankton, showing the same pattern of density of species in the three campaigns for each period. Through the rarefaction curves reconstructed, the largest number of species occurred during summer, when the curves remained growing, while in winter such curves tended to stabilize (Fig. 7).

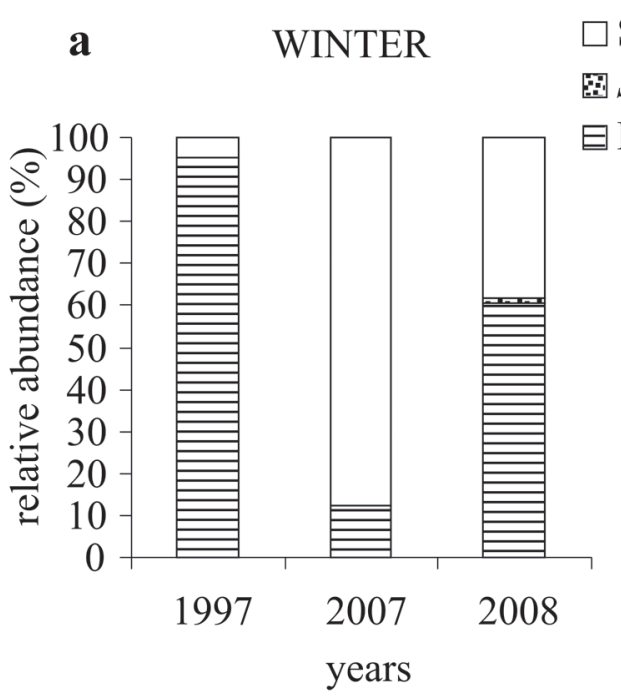

b $\quad$ SUMMER $\quad \square$ SI ㄱ. S. brasiliensis $\equiv$ Engraulidae

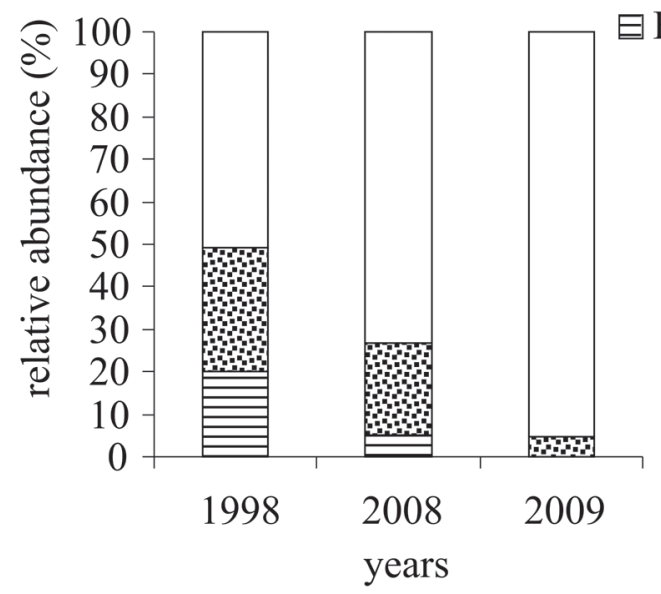

Fig. 4. Relative abundance (\%) of eggs collected in the Arvoredo Biology Marine Reserve (Brazil) during the winter (a) and summer (b) in campaign 1 (1997/1998), 2 (2007/2008) and 3 (2008/2009). SI: not identified species. 
Table 2. Larval fish collected the Arvoredo Biology Marine Reserve (Brazil) region, during the winter and summer period in campaign 1 (1997/1998), 2 (2007/2008), and 3 (2008/2009). Note: RA - Relative Abundance; FO - Frequencies of Occurrence; SE - Standard Error.

\begin{tabular}{|c|c|c|c|c|c|c|c|c|}
\hline \multirow{3}{*}{ Taxa } & \multicolumn{4}{|c|}{ WINTER } & \multicolumn{4}{|c|}{ SUMMER } \\
\hline & \multicolumn{4}{|c|}{ Density } & \multirow{3}{*}{ RA (\%) } & \multirow{3}{*}{ FO (\%) } & \multicolumn{2}{|c|}{ Density } \\
\hline & RA (\%) & FO (\%) & Mean & $\mathrm{SE}( \pm)$ & & & Mean & SE $( \pm)$ \\
\hline Clupeiformes & 1.5 & 6.7 & 0.07 & 0.05 & & & & \\
\hline Clupeidae & & & & & 0.5 & 3.3 & 0.09 & 0.09 \\
\hline Sardinella brasiliensis (Steindachner, 1879) & & & & & 7.8 & 13.3 & 0.31 & 0.19 \\
\hline Opisthonema oglinum (Lesueur, 1818) & & & & & 3.4 & 13.3 & 0.28 & 0.17 \\
\hline Harengula clupeola (Cuvier, 1829) & & & & & 7.8 & 30.0 & 0.78 & 0.25 \\
\hline Engraulidae & 68.4 & 89.7 & 7.44 & 1.32 & 9.8 & 23.3 & 0.98 & 0.46 \\
\hline Synodus intermedius (Spix, 1829) & & & & & 2.5 & 10.0 & 0.25 & 0.17 \\
\hline Cosmocampus elucens (Poey, 1868) & & & & & 0.5 & 3.3 & 0.02 & 0.02 \\
\hline Serranidae & & & & & 1.0 & 6.7 & 0.09 & 0.06 \\
\hline Carangidae & & & & & 2.9 & 3.3 & 0.27 & 0.27 \\
\hline Chloroscombrus chrysurus (Linnaeus, 1766) & & & & & 2.5 & 16.7 & 0.18 & 0.09 \\
\hline Oligoplites sp. & & & & & 2.5 & 10.0 & 0.26 & 0.16 \\
\hline Selene sp. & & & & & 2.9 & 16.7 & 0.29 & 0.14 \\
\hline Gerreidae & & & & & 15.2 & 20.0 & 1.46 & 0.67 \\
\hline Haemulidae & & & & & 1.5 & 10.0 & 0.20 & 0.11 \\
\hline Sciaenidae & 4.9 & 27.6 & 0.49 & 0.28 & 5.9 & 33.3 & 0.51 & 0.16 \\
\hline Stellifer $\mathrm{sp}$. & 1.1 & 10.3 & 0.15 & 0.08 & & & & \\
\hline Stegastes sp. & & & & & 1.0 & 6.7 & 0.10 & 0.07 \\
\hline Mugil sp. & 1.1 & 3.4 & 0.14 & 0.14 & 2.5 & 16.7 & 0.22 & 0.09 \\
\hline Labrisomidae & 0.4 & 3.4 & 0.06 & 0.06 & 0.5 & 3.3 & 0.04 & 0.04 \\
\hline Malacoctenus delalandii (Valenciennes, 1836) & & & & & 2.0 & 10.0 & 0.19 & 0.12 \\
\hline Blenniidae & & & & & 1.0 & 3.3 & 0.02 & 0.02 \\
\hline Hypleurochilus fissicornis (Quoy \& Gaimard, 1824) & 3.4 & 20.7 & 0.22 & 0.09 & 3.4 & 10.0 & 0.31 & 0.26 \\
\hline Parablennius pilicornis (Cuvier, 1829) & 2.3 & 6.7 & 0.31 & 0.23 & & & & \\
\hline Scartella cristata (Linnaeus, 1758) & 0.4 & 3.4 & 0.03 & 0.03 & 5.4 & 36.7 & 0.59 & 0.15 \\
\hline Gobiidae & 8.7 & 24.3 & 1.09 & 0.50 & 5.9 & 20.0 & 0.58 & 0.28 \\
\hline Sphyraena sp. & & & & & 1.0 & 6.7 & 0.04 & 0.04 \\
\hline Trichiuridae & & & & & 0.5 & 3.3 & 0.05 & 0.05 \\
\hline Trichiurus lepturus Linnaeus, 1758 & 0.4 & 3.4 & 0.06 & 0.06 & & & & \\
\hline Paralichthyidae & 0.4 & 3.4 & 0.04 & 0.04 & 3.4 & 13.3 & 0.36 & 0.19 \\
\hline Etropus crossotus Jordan \& Gilbert, 1882 & 0.8 & 3.4 & 0.05 & 0.05 & & & & \\
\hline Etropus sp. & 0.4 & 3.4 & 0.05 & 0.05 & & & & \\
\hline Paralichthys sp. & 1.5 & 10.3 & 0.19 & 0.11 & & & & \\
\hline Pleuronectidae & 0.4 & 3.4 & 0.05 & 0.05 & & & & \\
\hline Achiridae & 0.4 & 3.4 & 0.04 & 0.04 & & & & \\
\hline Not identified species & 3.0 & 20.7 & 0.35 & 0.14 & 6.9 & 26.7 & 0.32 & 0.15 \\
\hline
\end{tabular}

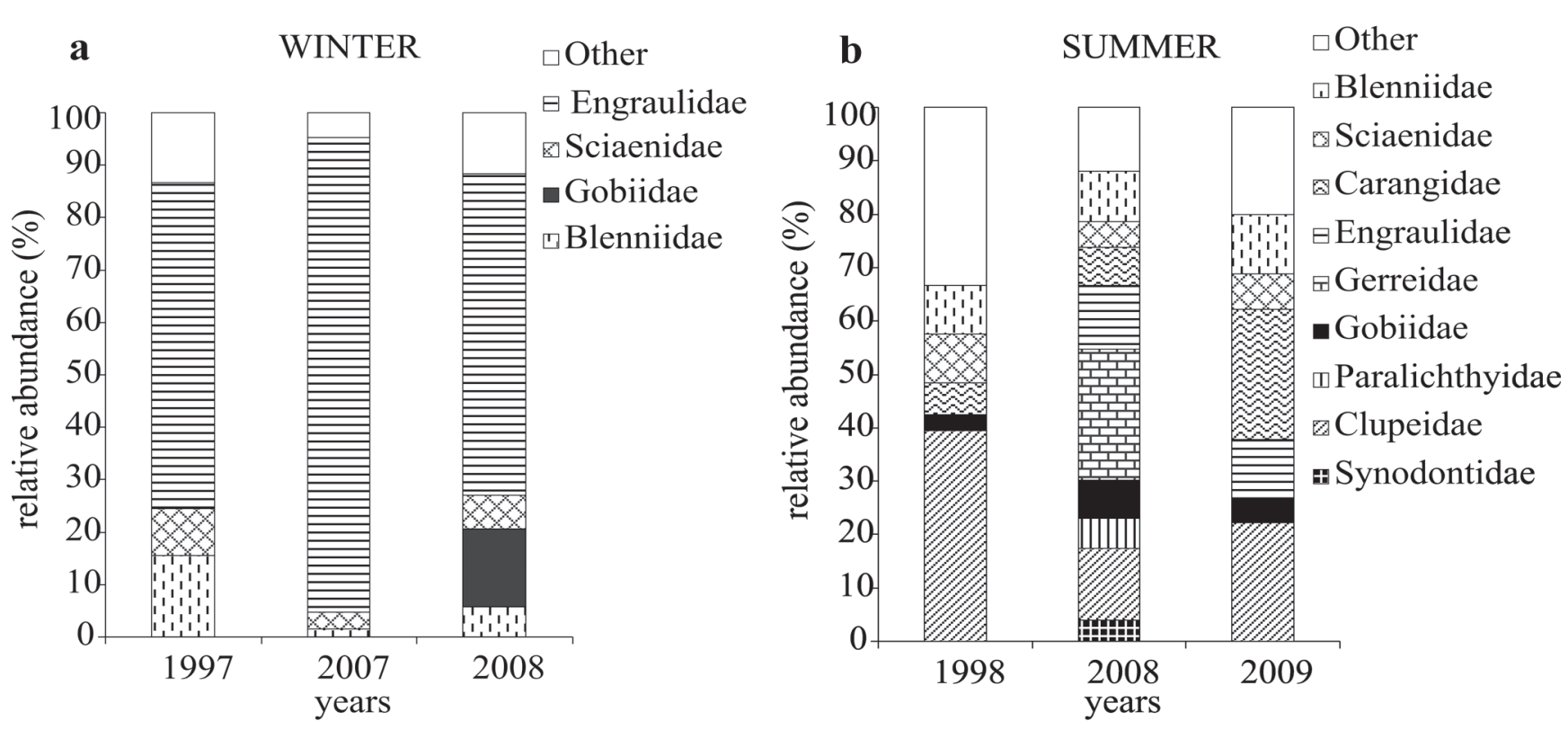

Fig. 5. Relative abundance (\%) of larvae collected in Arvoredo Biology Marine Reserve (Brazil) during winter (a) and summer (b). In campaign 1 (1997/1998), 2 (2007/2008) and 3 (2008/2009). 


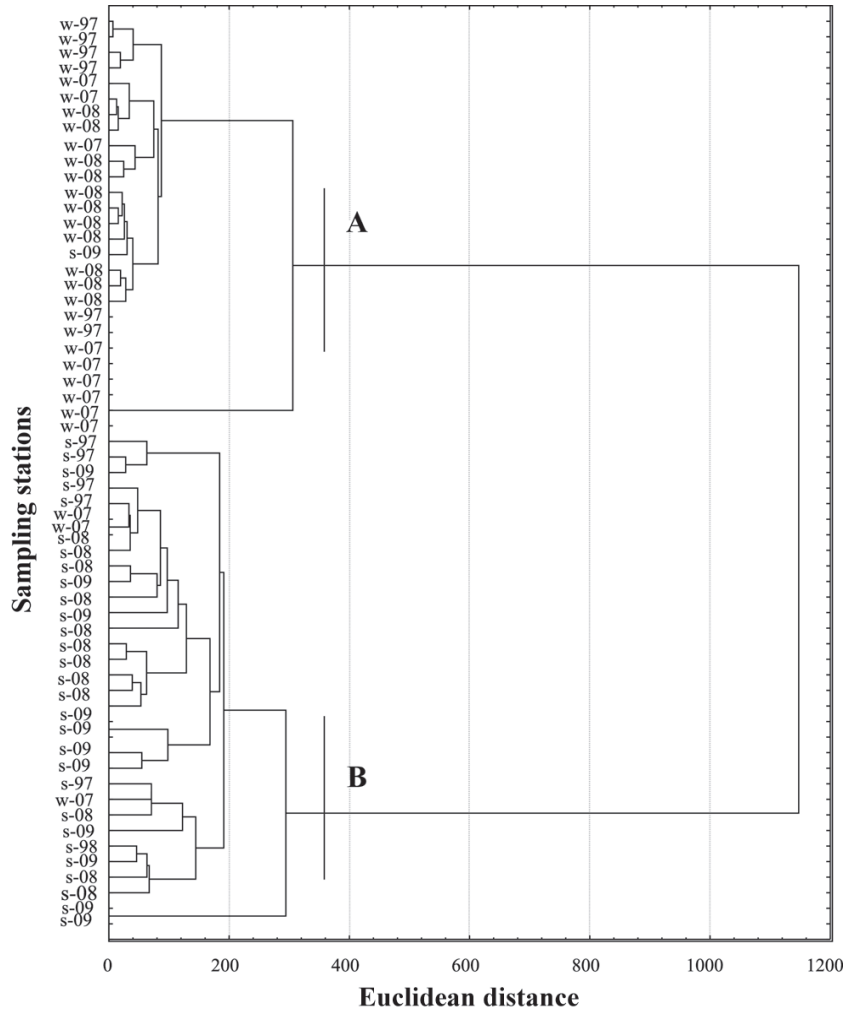

Fig. 6. Cluster analysis of 59 samples collected in the Arvoredo Biology Marine Reserve (Brazil) region during the summer (1998, 2008 and 2009) and winter (1997, 2007, and 2008), based on relative abundance of the different taxa fish larvae identified. Note: $\mathrm{w}$ - Winter; s - Summer

The study area was characterized by the presence of three water masses: Coastal Water (CW), Subtropical Shelf Water (STSW) and South Atlantic Central Water (SACW). In winter period, two water masses were registered, the $\mathrm{CW}$ with salinities varying from 29 to 31 and temperatures from 15 to $19^{\circ} \mathrm{C}$, and the STSW with salinities varying from 33 to 36 and temperatures from 17 to $20^{\circ} \mathrm{C}$ (Fig. 8a-b). In summer the $\mathrm{CW}$ was present with salinities varying from 27 to 32 and temperatures from 25 to $27^{\circ} \mathrm{C}$. In this period was also recorded the $\mathrm{SACW}$, with salinities varying from 35 to 36 and temperatures from 17 and $19^{\circ} \mathrm{C}$ (Fig. $8 \mathrm{c}-\mathrm{d}$ ). The water column profile observed demonstrate a thermohaline stratification during summer in Campaigns 2 and 3 (Fig. 9).

When both biotic and environmental data were analised through a canonical correspondence, a direct relationship between the abundance of Engraulidae and chlorophyll- $a$ was found, with a preference for lower water temperatures. Clupeidae occurred mainly when the water transparency was higher, while the Sciaenidae was associated with higher salinities. It was also confirmed that at higher temperatures a greater number of families was present in the ABMR (Fig. 10).

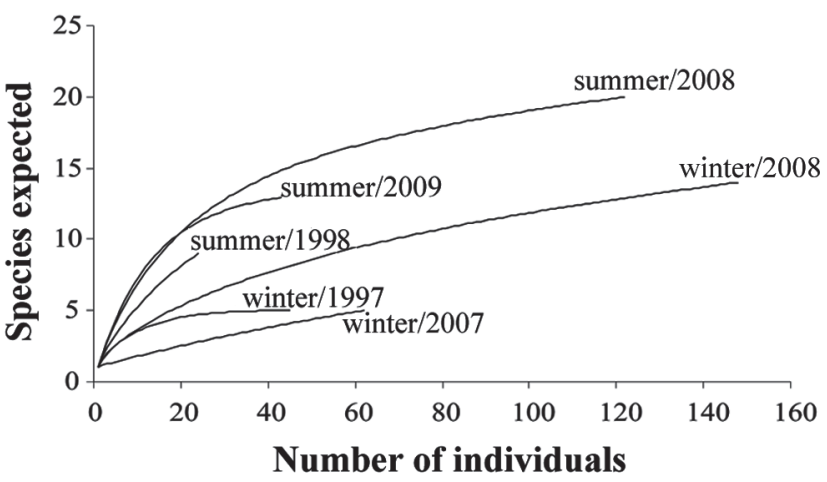

Fig. 7. Rarefaction curve of larval fish species collected during six sampling periods in the Arvoredo Biology Marine Reserve (Brazil) region.

\section{Discussion}

The ichthyoplankton in the region of the Arvoredo Biology Marine Reserve (ABMR) showed different patterns in densities between winter and summer, and among years as well. The highest densities of eggs were registered during the winter, mostly represented by the family Engraulidae. The winter of 2007 showed low density of eggs, significantly difference to the other winter campaigns, fact that reflects the low occurrence of the Engraulidae eggs in this period. This family has a short life cycle and high reproductive capacity (r-strategists), standing out as one of the most abundant in southeastern Brazil, especially in winter months (Matsuura et al., 1992; Matsuura \& Kitahara, 1995; Katsuragawa et al., 1993). Moreover, eggs of Clupeidae (Sardinella brasiliensis) were recorded only in the summer months, with a decrease tendency in the density of the years analyzed. Several authors (Lluch-Belga et al., 1989; Barange \& Hampton, 1997) reported that when anchovies occur together with sardine species in temperate waters their abundances seems to be inversely correlated, fact that can be verified in ABMR.

Anchovy and sardine species presumably compete for food, at least at some stage in their life history (Blaxter \& Hunter, 1982; Whitehead et al., 1988). Their relative abundance may oscillate as a result of complex ecological relationships between the two species, also affected by predation mortality and human exploitation (Schwingel, 1998). Studies on the food spectrum of adult and larvae of Clupeidae and Engraulidae show that are planktophagous (Blaxter \& Hunter, 1982; Schwingel, 1998; Schneider \& Schwingel, 1999). Although these families compete for food, the patterns observed in the ABMR could be a reflection of the quality of food available. Vasconcellos et al. (1998) show that the feeding success of anchovy larvae off southern Brazil was higher during austral winter. Higher feeding success rates during winter are apparently related to the combined effects of freshwater run-off and the flow of cold waters of Subantartic origin, which result in a strong vertical water stability over 
the shelf, fact related in the present study for the winter 2007 and 2008, where the Engraulidae represented $90 \%$ and $60 \%$ of the fish larvae in ABMR, respectively.

The identification of larvae in the region of the ABMR was difficult in the lowest levels. This fact may reflect the methodology used, the net with a mesh of $200 \mathrm{~mm}$. Smith \& Richardson (1977) describe that the most appropriate methodology for ichthyoplankton sampling are Bongo nets with meshes of 300 and $500 \mathrm{~mm}$. However, the $200 \mathrm{~mm}$ net was used to collect the zooplankton community around the island in ABMR, being a great opportunity to study de
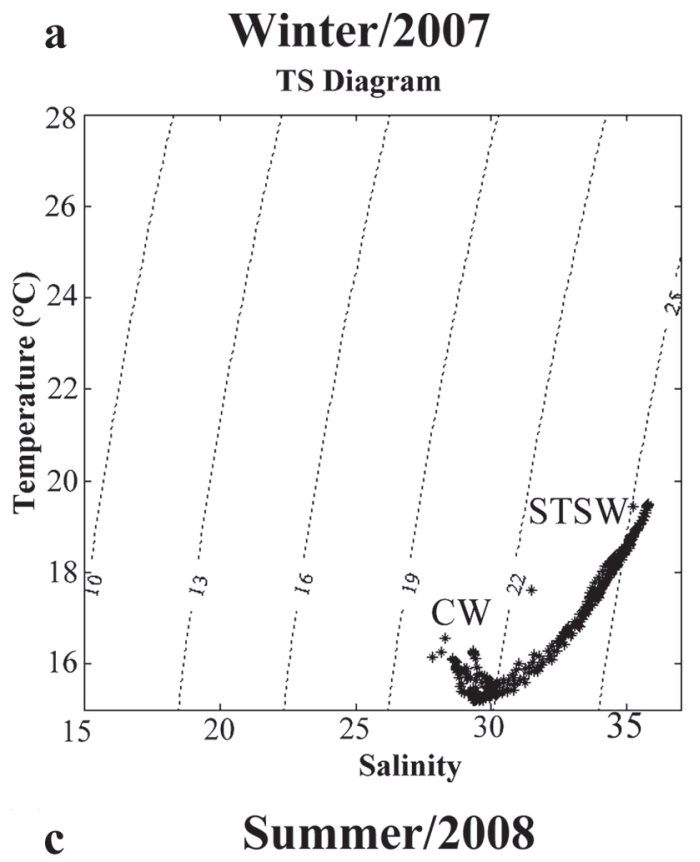

TS Diagram

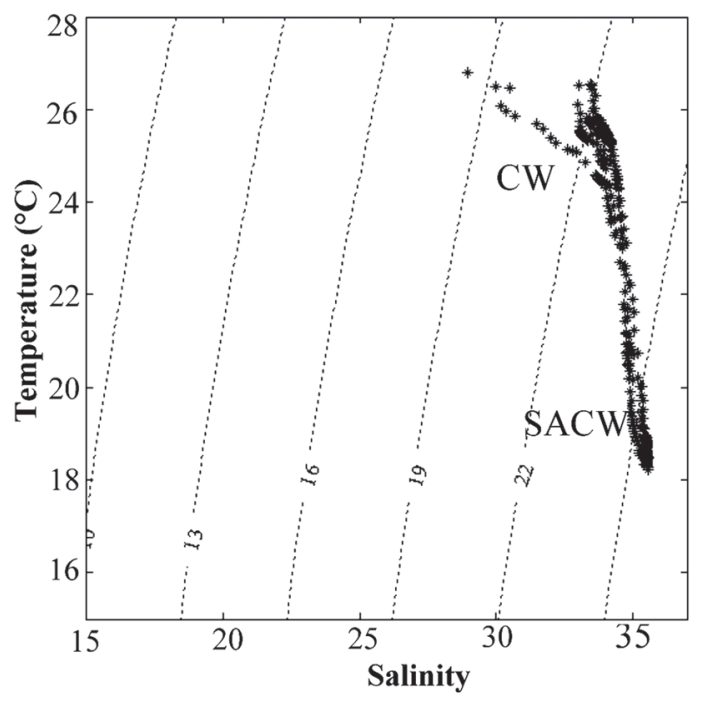

ichthyoplankton assemblages in the conservation unit

The family Engraulidae was the most abundant in winter $(>$ $50 \%$ ), resulting in a low variability and high dominance of this species in the environment. Conversely, a greater number of taxa were observed in summer, with similar abundances and lower dominance. During the summer, even if with low number of individuals, the richness of species was higher compared to the winter period. This pattern was observed in the three campaigns. Therefore, winter and summer seasons contribute to reproductive processes of different fish assemblages in the ABMR, including pelagic, demersal, and reef species.
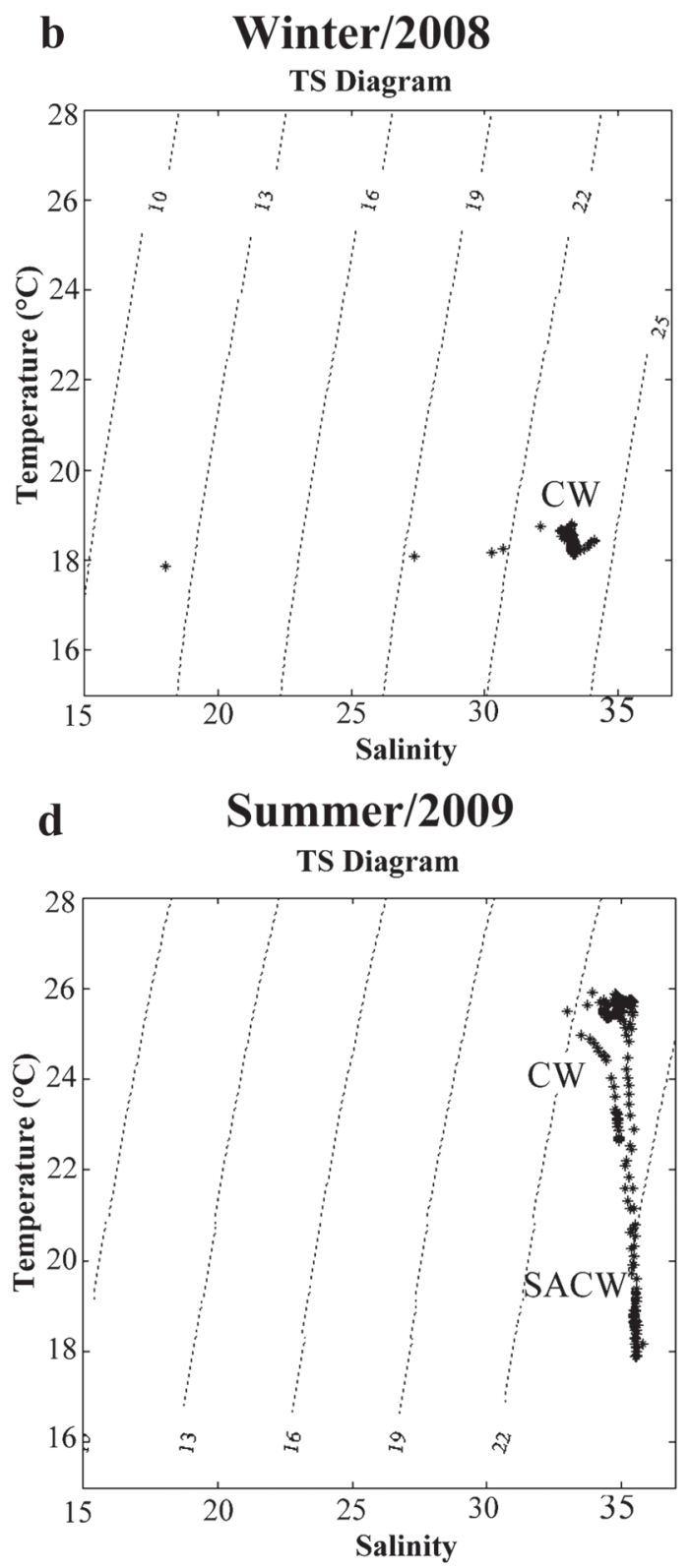

Fig. 8. Temperature and salinity of the water column (Diagram TS) recorded in Arvoredo Biology Marine Reserve (Brazil) region during winter/2007 (a), winter/2008 (b), summer/2008 (c), and summer/2009 (d). CW = Coastal Water; SACW = South Atlantic Central Water; STSW = Subtropical Shelf Water. 
The variation in densities of ichthyoplankton in the ABMR is influenced by environmental factors such as the dynamics of water masses that occur in the region. The thermohaline conditions verified in Campaign 3 showed a homogeneous water column in winter and stratified in summer, a typical pattern on the continental shelf of Santa Catarina Brazil (Carvalho et al., 1998, Hille et al., 2008), what could explain the differences in the densities of ichthyoplankton. In addition, the larvae composition revealed that the greatest abundance of Engraulidae and Gobiidae (representing 76.1\%) occurred during the winter and of Carangidae and Clupeidae (representing 46.6\%) during the summer. On the other hand, in Campaign 2 was verified the influence of the STSW during the winter, formed by mixing the SACW and the continental input of Rio de la Plata and Patos Lagoon (Piola et al., 2000). In the summer period, thermohaline stratification was observed, with the SACW always present in the deeper layer, as also described by Matsuura (1986). In this campaign there was no significant difference in the densities of ichthyoplankton among winter and summer, however, fish larvae assemblages in winter was compose by $90.5 \%$ of Engraulidae and in summer, nine families (Gerreidae, Clupeidae, Engraulidae, Blenniidae, Carangidae, Gobiidae, Paralichthyidae, Sciaenidae, and Synodontidae) represented $88.1 \%$. According to Freitas \& Muelbert (2004), the narrow width of the continental shelf between Itajaí $\left(27^{\circ} \mathrm{S}\right)$ to Cabo de Santa Marta Grande $\left(29^{\circ} \mathrm{S}\right)$, increase the influence of SACW on the coast in summer. Braga \& Niencheski (2006) described that the rise of SACW promotes a coastal upwelling increasing the nutrients in the photic zone, resulting in a high primary production, favoring the quantity and quality of the food supply for the ichthyoplankton.

In this sense, Kimberley \& Suthers (1999) and Rodriguez et al. (2004) described that high diversity and an a

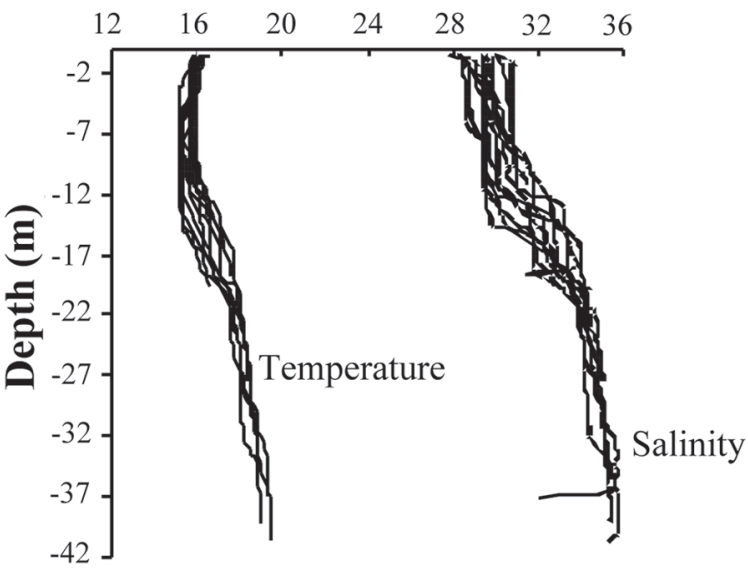

c

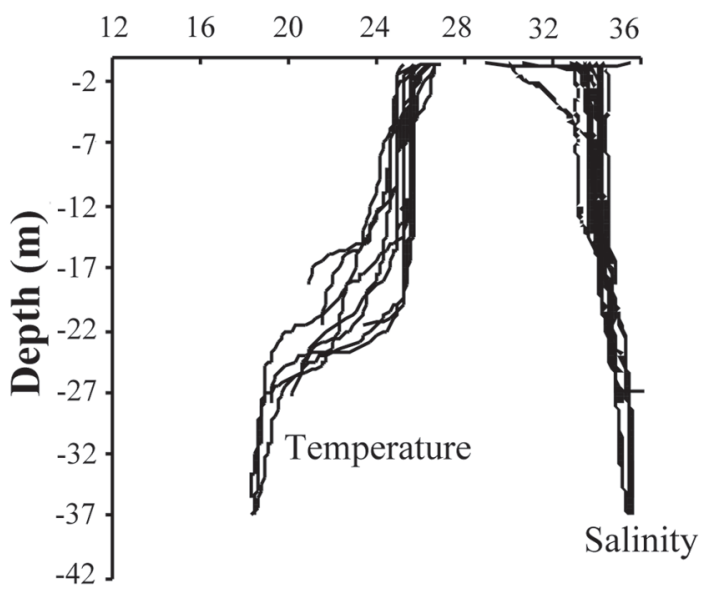

b

Winter $/ 2008$

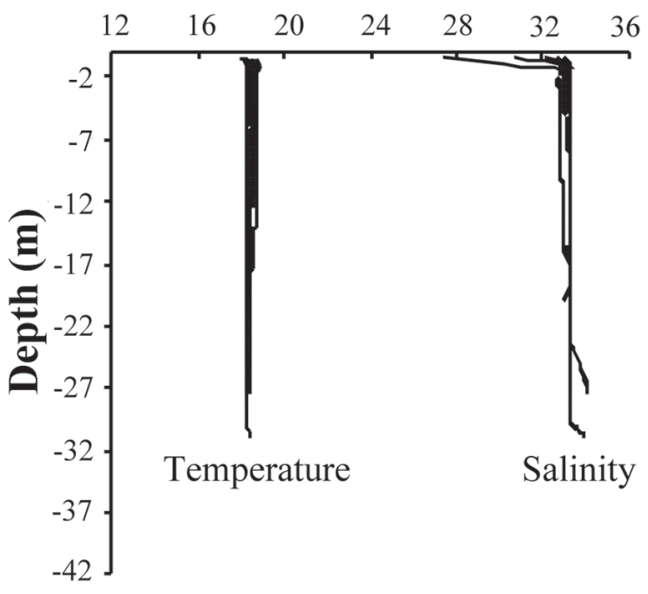

d

Summer/2009

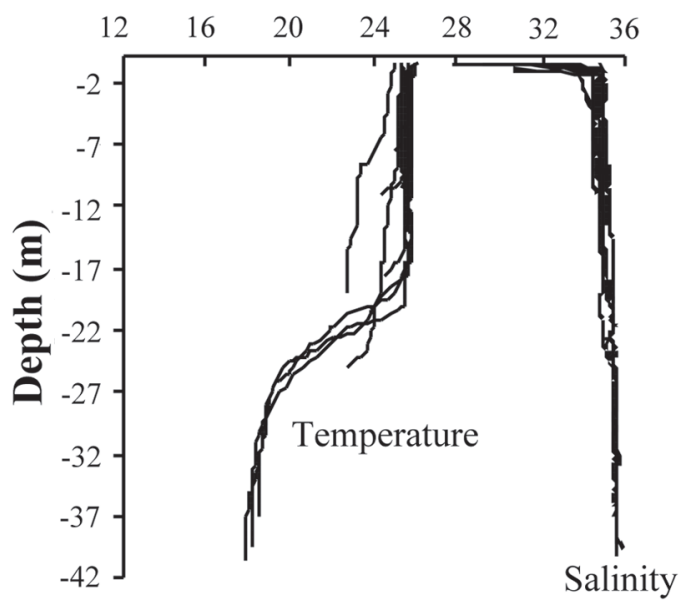

Fig. 9. Profile the temperature and salinity of the water column (Diagram TS) recorded in Arvoredo Biology Marine Reserve (Brazil) region during winter/2007 (a), winter/2008 (b), summer/2008 (c), and summer/2009 (d). 

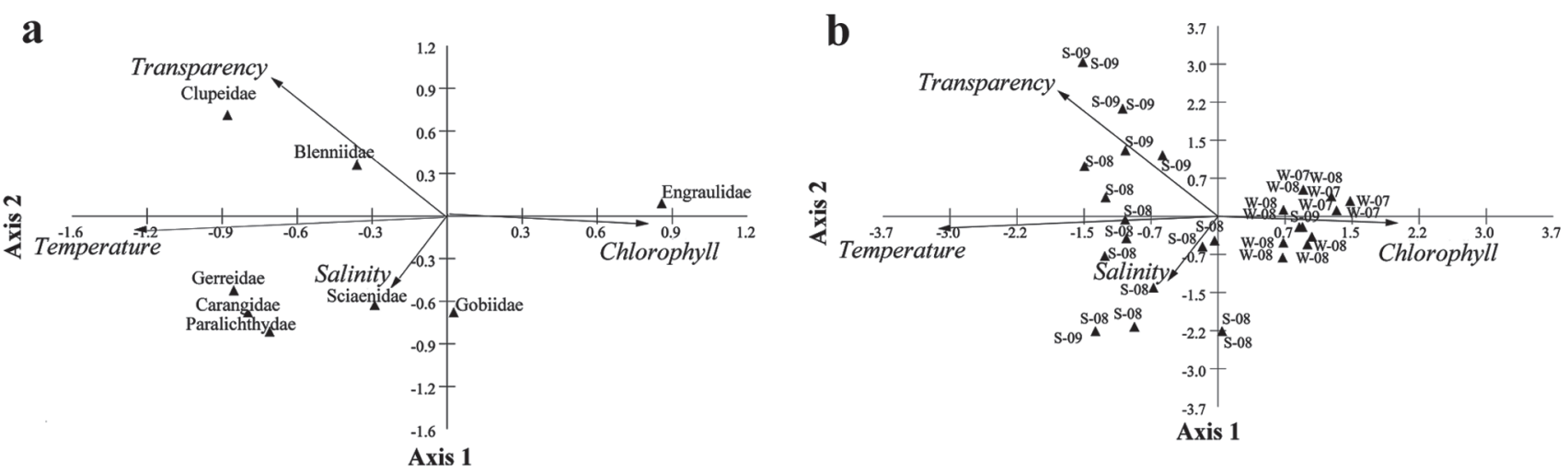

Fig. 10. Canonical Correspondence Analysis of the (a) eight most abundant families, and (b) stations in Arvoredo Biology Marine Reserve (Brazil) region in relation to temperature, salinity and chlorophyll- $a$. Note: W-07 - Winter/2007; S-08 - Summer/ 2008; W-08 - Winter/2008 and S-09 - Summer/2009

abundance of fish larvae can be seen in areas where coastal upwelling occurs. The occurrence of the SACW close to the islands of ABMR may be related to the mass effect on those promote on the local hydrodynamics. According Gilmart \& Revelante (1974), the mass island effect favors the increase of local primary production, associated to the local hydrodynamics with cyclonic and anticyclonic vortices (Barkley, 1972 apud Longhurts \& Pauly, 2007). Sabatés et al. (2003) showed that the effects of water mass transport may play an important role in the distribution of fish during the early life cycle. Franco-Gordo et al. (2003) confirmed this conclusion, identifying relationships between assemblages of ichthyoplankton and environment oceanographic pattern.

A canonical correspondence analysis and cluster analysis showed a strong seasonality in the region, and the thermohaline structure responsible for the taxonomic composition of the ABMR. The family Engraulidae occurred mainly at low temperatures and high concentrations of chlorophyll-a. According Noernberg et al. (2007) high values of chlorophyll during the winter season in Itajaí occurred due to fertilization of shelf-waters caused by cold water coming from the South. The distribution of the taxa at ABMR reflects the influence of the local environment however, the standard spawning of adults should also be considered, which reflects the formation of assemblages of fish larvae (Somarakis et al. 2002). Hostim-Silva et al. (2006) listed the adult fish species found in ABMR, which is consistent with the types of larvae identified in this work. Taxonomic composition of ichthyoplankton in ABMR showed seasonal patterns in the 3 periods sampled. The ichthyoplanktonic assemblage remained at the same rate and abundance after a period of 10 years. This may be a condition to use this area as a reference for future studies of environmental impact on the marine environment in the region.

The high number of families and abundance of plankton observed in ABMR may play a role in enriching the adjacent coastal areas impacted by fishing. This relationship was observed by Sabatés et al. (2003) in the Medes Island Marine Reserve (Mediterranean), where species richness and large concentrations of fish larvae were distinct from the nearby coastal regions. Pelc et al. (2010), suggests that export of larvae, which are produced in the reserves to adjacent areas may be sufficient to offset the increased mortality due to fishing effort outside reserves. On the other hand, the benefits of marine protected areas do not apply to all species of fish, and the answers to the protection can be highly variable (Claudet, et al., 2006). Russ et al. (2004) observed for Reserve Apo Island (Philippines) that biomass of Carangidae and Acanthuridae tripled in a protected area in the period of 18 years, however, fishing in the adjacent area did not change significantly during the same period. Authors also described the benefits of marine reserves for the region: higher catch rates, less fishing effort and enhancement or at least maintenance of total catch. In a review, Gell \& Roberts (2003) showed that 24 years after the implementation of Merritt Island National Wildlife Refuge (USA), fishes of family Sciaenidae and Centropomidae were more abundant and bigger, where compared with surrounding fishery areas. In the case of the ABMR, the fact that fish larvae composition and abundance was similar after 10 years, indicated a important role of the reserve for the conservation, considering the high fishing effort off southern Brazil. At the same time, the management measures in the surrounding areas of the reserves are needed to supply the protection offered by conservation areas (Roberts et al., 2005). However, the elucidation of the relationships between the productivity of fisheries and conservation of natural resources need further research, especially to define the maintenance or enlargement of ABMR area.

\section{Acknowledgements}

We sincerely thank Rafael Schroeder for his support, practical suggestions and most of all for his critical reading of the manuscript. 


\section{Literature Cited}

Barange, M. \& I. Hampton. 1997. Spatial structure of co-occurring anchovy and sardine population from acoustic data: implications for survey desing. Fisheries Oceanography, 6: 94-108.

Blaxter, J. H. S. \& J. R. Hunter. 1982. The Biology of the Clupeoid Fishes. Advances in Marine Biology. Academic Press, 223p.

Bohnsack, J. A. 1999. Incorporating No-Take Marine Reserves into Precautionary Management and Stock Assessment. NOAA Technical Memorandum, 8-16.

Braga, E. S. \& L. F. H. Niencheski. 2006. Composição das massas de água e seus potenciais produtivos na área entre o Cabo de São Tomé (RJ) e o Chuí (RS). Pp. 161-218. In: RossiWongtschowski, C. L. D. B. \& L. S. P. Marureira (Eds.). O ambiente oceanográfico da plataforma continental e do talude na região Sudeste-Sul do Brasil. Brasil, 644p.

Carvalho, J. L. B., C. A. F. Schettini \& T. M. Ribas. 1998. Estrutura termohalina do litoral centro-norte catarinense. Notas Técnicas da FACIMAR, 2: 181-197.

Castro, B. M., J. A., Lorenzzetti, I. C. A. Silveira \& L. B. Miranda. 2006. Estrutura termohalina e circulação na região entre Cabo de São Tomé (RJ) e o Chuí (RS). Pp. 11-120. In: RossiWongtschowski, C. L. D. B. \& L. S. P. Marureira (Eds.). O ambiente oceanográfico da plataforma continental e do talude na região Sudeste-Sul do Brasil. Brasil, 644p.

Claudet, J., D. Pelletier, J. Y. Jouvenel, F. Bachet \& R. Galzin. 2006. Assessing the effects of marine protected area (MPA) on a reef fish assemblage in a northwestern Mediterranean marine reserve: Identifying community-based indicators. Biological Conservation, 130: 349-369.

Fahay, M. P. 1983. Guide to the early stages of marine fishes occuring in the Western North Atlantic Ocean, Cape Hatteras to the Southern Scotian Shelf. Journal Northwest Atlantic Fishery Science. Canada, 423p.

Franco-Gordo, C., E. Godínez-Domínguez, E. Suárez-Morales \& L. Vásquez-Yeomans. 2003. Diversity of ichthyoplankton in the central Mexican Pacific: a seasonal survey. Estuarine. Coastal and Shelf Science, 57: 111-121.

Freitas, D. M. \& J. H. Muelbert. 2004. Ichthyoplankton Distribution and Abundance off Southeastern and Southern Brazil. Brazilian Archives of Biology and Technology, 47: 601-612.

Gell, F. R. \& C. M. Roberts. 2003. Benefits beyond boundaries: the fishery effects of marine reserves. TRENDS in Ecology and Evolution, 18: 448-455.

Gilmartin, M. \& N. Revelante. 1974. The 'Island Mass' effect on the phytoplankton and primary production of the Hawaiian Islands. Journal of Experimental Marine Biology and Ecology, 16: 181-204.

Gotelli, N. J. \& A. M. Ellison. 2004. A Primer of Ecological Statistics. Sunderland. Massachusetts, 510p.

Hilborn, R., K. Stokes, J. J. Maguire, T. Smith, L. W. Botsford, F. Mangel, J. Orensanz, A. Parma, J. Rice, J. Bell, K. L. Cochrane, S. Garcia, S. J. Hall, G. P. Kirkwood, K. Sainsbury, G. Stefansson \& C. Walters. 2004. When can marine reserves improve sheries management? Ocean \& Coastal Management, 47: 197-205.

Hille, E., C. A. F. Schettini \& M. Rodrigues-Ribeiro. 2008. Estrutura Termohalina no Litoral de Santa Catarina Nos Anos de 2005 e 2006. Pp. 371-382. In: Braga, E. S. (Org.). Oceanografia e Mudanças Globais. São Paulo, 784p.

Hostim-Silva, M., A. B.,Andrade, L. F.,Machado, L. Gerhardinger, F. A. Daros, J. P. Barreiros \& E. G. A. Souza. 2006. Peixes de costão rochoso de Santa Catarina - I. Arvoredo. Brasil, 135p.
IBAMA (Instituto Brasileiro do Meio Ambiente e dos Recursos Naturais Renováveis). 2006. Listas das Unidades de Conservação Federais: Reserva Biológica Marinha do Arvoredo. Brasília, 56p.

IBAMA/GTZ (Instituto Brasileiro do Meio Ambiente e dos Recursos Naturais Renováveis/Cooperação Técnica Alemã). 1999. Criação das Unidades de Conservação. Brasília, 27p.

Katsuragawa, M., Y. Matsuura, K. D. J. F. Suzuki \& H. L. Spach. 1993. O ictioplâncton ao largo de Ubatuba, SP: composição, distribuição e ocorrência sazonal (1985-1988). Boletim Instituto Oceanográfico, 10: 85-121.

Kimberley, A. S. \& I. M. Suthers. 1999. Displacement of diverse ichthyoplankton assemblages by a coastal upwelling event on the Sydney shelf. Marine Ecology Progress Series, 176: 49-62.

Lluch-Belga, D., R. J. M. Crawford, T. Kawasaki, A. D. MacCall, R. H. Parrish, R. A. Schwartzlose \& P. E. Smith. 1989. World-wide flutuations of sardine and anchovy stocks: the regime problem. South African Journal of Marine Science, 8: 195-205.

Longhurst, A. R. \& D. Pauly. 2007. Ecologia dos oceanos tropicais. Ed. USP, 424p.

Ludwig, J. A. \& J. F. Reynolds. 1988. Statistical Ecology A Primer on Methods and Computing. New York, John Wiley \& Sons, 337p.

Matsuura, Y. 1986. Contribuição ao estudo da estrutura oceanográfica da região sudeste entre Cabo Frio (RJ) e Cabo de Santa Marta Grande (SC). Ciência e Cultura, 38: 1439-1450.

Matsuura, Y., H. L. Spach \& M. Katsuragawa. 1992. Comparison of spawning patterns of the Brazilian sardine (Sardinella brasiliensis) and anchoita (Engraulis anchoita) in Ubatuba region, southern Brazil during 1985 through 1988. Boletim Instituto Oceanográfico, 40: 101-115.

Matsuura, Y. \& E. M. Kitahara. 1995 Horizontal and vertical distribution of anchovy Engraulis anchoita eggs and larvae off Cape Santa Marta Grande in southern Brazil. Archive of Fishery and Marine Research, 42: 239-250.

Moser, G. 1996. Early stages of fishes in the California Current Region, CalCOFI Atlas Series n`33. Sllen Press, USA, 1505p.

Noernberg, M. A., M. Kampel \& F. P. Brandini. 2007. Estudo da variabilidade temporal da concentração de clorofila estimada por satélite na plataforma continental catarinense: latitude $26^{\circ}$ 46' S. Anais XIII Simpósio Brasileiro de Sensoriamento Remoto. Florianópolis, Brasil, INPE, 4635-4642.

Pelc, R. A., R. R. Warner, S. D. Gaines \& C. B. Paris. 2010. Detecting larval export from marine reserves. Proceedings of the National Academy of Sciences of the United States of America, 107: 18266-18271

Piola, A. R., E. J. D. Campos, Jr. O. O. Moller, M. Charo \& C. Martinez. 2000. The subtropical shelf front of eastern South America. Journal of Geophisical Research, 105: 6565-6578.

Proença, L. A. O. 2002. Clorofila-a do fitoplâncton em seis enseadas utilizadas para o cultivo de moluscos bivalves no litoral de Santa Catarina. Notas Técnicas Facimar, 6: 33-44.

Ré, P. 1999. Ictioplâncton estuarino da Península Ibérica (Guia de identificação dos ovos e estados larvares planctônicos). Faculdade de Ciências da Universidade de Lisboa. Portugal, 78p.

Roberts, C. M., J. P. Hawkins \& F. R. Gelly. 2005. The role of marine reserves in achieving sustainable fisheries. Philosophical Transactions of the Royas Society Biological Sciences, 360: 123-132.

Rodríguez, J. M., E. D. Barton, S. Hernández-Léo \& J. Arístegui. 2004. The influence of mesoscale physical processes on the larval fish community in the Canaries CTZ, in summer. Progress in Oceanography, 62: 171-188. 
Rowley, R. J. 1994. Marine reserves in fisheries management. Aquatic Conservation: Marine and Freshwater Ecosystems, 4: 233-254.

Russ, G. R., A. C. Alcala, A. P. Maypa, H. P. Calumpong \& A. T. White. 2004. Marine Reserve benefits local fisheries. Ecological Applications, 14: 597-606.

Sabatés, A., M. Zabala \& A. García-Rubies. 2003. Larval fish communities in the Medes Islands Marine Reserve (North-west Mediterranean). Journal of Plankton Research, 25: 1035-1046.

Schneider, F. \& P. R. Schwingel. 1999. Estudo preliminar da ecologia trófica da Sardinella Brasiliensis na costa sudeste do Brasil. Notas Técnicas Facimar, 3: 67-72.

Schwingel, P. R. 1998. Feeding Ecology of Engraulis anchoita (Hubbs \& Marini 1935) in Brasilian Waters $\left(22^{\circ} \mathrm{S}\right.$ to $\left.34^{\circ} \mathrm{S}\right)$. Unpublished Ph.D. Dissertation, Universidade de Hamburg, Alemanha, 204p.

Somarakis, S., P. Drakopoulos \& V. Filippou. 2002. Distribution and abundance of larval fish in the northern Aegean Sea-eastern Mediterranean - in relation to early summer oceanographic condition. Journal of Plankton Research, 24: 339-357.

Smith, P. E. \& S. L. Richardson. 1977. Standard techniques for pelagic fish egg and larvae survey. FAO, Fisheries Technical Paper, 175: 1-100.

Ter Braak, C. J. F. 1986. Canonical correspondence analysis: a new eigenvector technique for multivariate direct gradient analysis. Ecology, 67:1167-1179.

Vasconcellos, M. C., K. F. Freire \& J. P. Castello. 1998. Distribution patterns and feeding success of anchovy, Engraulis anchoita, larvae off southern Brazil. Scientia Marina, 62: 385-392.

Whitehead, P. J. P., G. J. Nelson \& T. Wongratana. 1988. FAO species catalogue. Clupeoid fishes of the world (Suborder Clupeoidei). An annotated and illustrated catalogue of the herrings, sardines, pilchards, sprats, anchovies and wolf-herrigs. Part 2. Engraulidae. FAO Fisheries Synopsis, 125: 305-579.

Zar, J. H. 1984. Biostatistical Analysis. 2 ed. Prentice-Hall, Englewood Cliffs, New Jersey, 718p.

Submitted August 25, 2010

Accepted October 14, 2011

Published December 26, 2011 